Wojciech Zyzak

The Pontifical University of John Paul II in Cracow, Poland

\title{
Call of Lay People to the Mystical Life
}

\section{Abstract}

The subject of this article is the call of lay people to the mystical life. The topic under consideration indicates two poles, around which the main reflection revolves: the mystic and the lay state of life. The call of lay people to mysticism is not just a hypothesis, but a real experience, researched and decribed by theologians. So reflecting on the call to the mystic life of lay people is not so much a matter of 'whether', but of 'how'. In the light of the above, four issues are fundamental: the impossibility to provoke the mystical experience, its dependence on the spirituality of the baptism, the relation of contemplation to action and the relation to the world. It occurs however, that every Christian, together with God's life of grace bestowed in baptism, receives the basis for the mystical life. Neither an active life in the world, nor work or marriage, hinders the development of this gift.

\section{Keywords}

Spirituality, mysticism, laity, contemplation, action, baptism, world.

\section{Introduction}

The topic of our consideration indicates two poles, around which the main reflection should revolve: the mystic and the lay state of life. We admit that Christian mysticism is a conscious experience of the personal unification with God, who first takes the initiative and offers himself in a non-determining way. Alongside the conscious experience of God's presence in the soul, special attention must be paid to the free initiative of God, which however does not exclude the 
human effort necessary for the cooperation with His grace. Concerning the second pole of our reflection - according to the Council's definition - we consider as the lay people, 'all the faithful except those in holy orders and those in the state of religious life specially approved by the Church. These faithful are by baptism made one body with Christ and are constituted among the People of God; they are in their own way made sharers in the priestly, prophetical, and kingly functions of Christ; and they carry out for their own part the mission of the whole Christian people in the Church and in the world. What specifically characterizes the laity is their secular nature'"

Right from the beginning we have to mention, that the call of lay people to mysticism is not just a hypothesis, but a real experience, researched and decribed by theologians. We can count among the most well known mystics of the $20^{\text {th }}$ century the flowing individuals: Gemma Galgani (1878-1903), Martha Robin (1902-1981), Camille Crowet (1900-1971), Madeleine Delbrêl (1904-1964) and Jeanne Schmitz-Rouly (1891-1979)2. It seems that Saint John of the Cross, writing a letter to Joanna de Pedraza, interprets her spiritual condition as the 'dark night's. So reflecting on the call to the mystic life of the lay people is not so much a matter of 'whether', but of 'how'. In the light of the above, four questions are fundamental: the impossibility to provoke the mystical experience, its dependence on the spirituality of the baptism, the relation of contemplation to action and the relation to the world.

\section{The necessity of God's initiative and the impossibility to provoke the mystical experience}

Mystical experience in the life of the lay people is a fact. What is more, H. Caffarel in his descriptions of the experiences of the aforementioned Camille Crowet suggests, that God bestowed upon her the feeling of His presence when she was still an atheist. This allows the problem of the mystical experience to be put in a wider context, which Saint John expresses in the following sentence: ,tò $\pi v \varepsilon v \mu \alpha$ ó $\pi$ ov $\theta \varepsilon ́ \lambda \varepsilon \iota ~ \pi v \varepsilon \imath "(\mathrm{~J} \mathrm{3,} \mathrm{8).} \mathrm{In} \mathrm{agreement} \mathrm{with} \mathrm{J.} \mathrm{Maritain,} \mathrm{who} \mathrm{said} \mathrm{that}$

${ }^{1}$ Dogmatic Constitution on the Church Lumen Gentium, Nr. 31.

${ }^{2}$ See F.-M. Léthel, La communion aimante à la Passion de Jésus: sainte Gemma Galgani, "Carmel" 3 (1999) 93, p. 3-16; J. Bouflet, Marthe Robin ou la toute-petitesse en Dieu, ibid, p. 27-38; P. Verdeyen, Une lettre inédite de C. Camille, ibid, p. 41-48; J.- Ph Houdret, Un témoin de l'Évangile en notre temps: Madeleine Delbrêl, ibid, p. 51-57; M. H. de Longchamp, Le bonheur d'aimer Dieu: Jeanne Schmitz-Rouly, ibid, p. 73-85.

${ }^{3}$ See San Juan de la Cruz, Letter 19, in: Obras Completas, Salamanca 2002, p. 1064. 
natural mystical contemplation does not exist, we have to accept the thesis of the presence of God's grace beyond the visible belonging to the Church, which can be the basis of the mystical experience even beyond Christianity.

We can find some comments on the subject in the life and work of Edith Stein. In connection with the three ways of the dwelling of God in the soul, through His essence, His grace and spiritual experience, distinguished by Saint John of the Cross, she leads us towards the experience of God's presence in the soul ${ }^{4}$. Edith compared faith to the state in which one has heard a lot of good about somebody. That somebody has proved his goodness with deeds, which leads to gratitude and an increase in the desire to get to know him personally. However the grace of the encounter will be given only in the higher, mystical way of knowing, in which God bestows a personal meeting, touching the centre of the soul ${ }^{5}$. The passing from the natural way of knowing God to the supernatural experience can be, in her opinion, compared with the personal encounter with somebody, whose existence was known earlier from the effects of his activity. The faith can build a bridge to this passing. Nevertheless, in the key sentence, Edith maintains that if we consider this passing without the mediation of faith - as an experience of God bestowed upon a non-believer - it causes various types of fulfillment and has the character of an inner impact and change, for together with this experience faith is given ${ }^{6}$.

In the light of the above it is worth asking a risky question in how far these considerations have an autobiographical character. In most cases when writing about E. Stein as a mystic, one takes into consideration her life in $\mathrm{Carmel}^{7}$. Meanwhile the question arises what experience she is talking about, when she says that suddenly the world of faith stood before her (die Welt des Glaubens stand plötzlich vor mir) ${ }^{8}$. Edith is very discrete in her descriptions of experiences, but as a person who had considered herself until recently an atheist, to be able to say 'it is true' after having read 'Life' by Saint Teresa of Avila, must have had an experience of something similar to what was written in this book ${ }^{9}$.

${ }^{4}$ See San Juan de la Cruz, Cántico espiritual, in: Obras Completas, p. 616.

${ }^{5}$ See E. Stein, Kreuzeswissenschaft. Studie über Johannes vom Kreuz, Freiburg im Breisgau 2003, p. 148.

${ }^{6}$ See E. Stein, Wege der Gotteserkenntnis. Die Symbolische Theologie des Areopagiten und ihre sachlichen Voraussetzungen, Freiburg im Breisgau 2003, p. 48.

${ }^{7}$ See E. García Rojo, Edith Stein. Existencia y pensamiento, Madrid 1998, p. 175.

${ }^{8}$ See E. Stein, Aus dem Leben einer jüdischen Familie, Freiburg im Breisgau 2002, p. 210.

${ }^{9}$ See R. Leuven, Heil im Unheil, Freiburg - Basel - Wien 1983, p. 42. 
It is worth noting the very early work of Edith, namely 'Introduction to philosophy'. The beginning of this manuscript was connected directly with her doctor's thesis (published in 1917), and was written at the latest in 1921, i.e. before her baptism ${ }^{10}$. In this text we can find a clear description of the feeling of safety and security (Geborgenheitserlebnisses), which characterizes her experience in the period of her life, when she considered herself as an atheist. If this example of Stein confirms the thesis, that God is free to let anybody experience His presence in the soul, regardless of their state of life and even their religion, it is also true, that it is exceptional. Generally, the case of the mystical life is to do with certain subjective conditions, which prepare a person for the reception of the conscious experience of God. The task of the following will be to investigate how far such conditions can be realized in the life of lay faithful, who, according to the Council's definition, through baptism, are grafted in Christ, and fulfill their proper mission in the Church and in the world with their specific lay character.

\section{The Baptism as a basis for the common calling to the mystical life}

In the writings of the Blessed Elisabeth of the Trinity we often meet the opinion that through baptism man becomes grafted in Christ and the whole Trinity. Due to this, he becomes God's child, anointed with the seal of God. The Holy Spirit, when choosing a Christian for His temple, imprints in his soul the image of Christ, through which he is no longer himself, but Christ. According to Elisabeth, the highest Christian perfection consists of such a union with God, that his image in the faculties of the soul is perfect ${ }^{11}$. The Trinitarian piety of Elisabeth is characterized by a special intimacy in relation with 'her Trinity'. Because for her, this piety is based on baptism, which makes a person 'a temple of the Trinity', she was eager to awaken this piety in every Christian who she could reach ${ }^{12}$. A long time before the Second Vatican Council, the Carmelite didn't try to write about the states of perfection in the Church, but about the common calling to the holiness, regardless of the way of life (chacun de nous doit être le saint de Dieu). According to her, the holiest and the most united with God is the person who loves Him the most. Such a love, which is the essence of holiness, was wished by the Blessed upon the lay

\footnotetext{
${ }^{10}$ See M. Linssen, Vorwort, in: E. Stein, Einführung in die Philosophie, Freiburg im Breisgau 1991, p. 5.

${ }^{11}$ See Élisabeth de la Trinité, Śuvres Complètes, Paris 2002, p. 99, 115, 137, 1027.

${ }^{12}$ See J.- P. Houdret, Élisabeth ou l'envahie des Trois. Sa dévotion pour la Trinité, in: Élisabeth de la Trinité. L'avanture mystique, Toulouse 2006, p. 261.
} 
people, like for instance Margaret Gollot ${ }^{13}$. The answer to this common call to the holiness is transformation into Christ (il faut être transformé en Jésus-Christ) ${ }^{14}$. Having reached this state, the soul - even though it is not always aware of it, for the weakness of its nature, which doesn't allow it to be constantly concentrated on God without distractions - adores unceasingly God, becoming Laudem gloriae (Louanges de glorie) of the Holy Trinity ${ }^{15}$. The awareness of God dwelling in the very center of the soul is the secret of happiness, which saints possess ${ }^{16}$. It is the secret, which Elisabeth wanted to show every Christian. That she didn't hesitate to demand heroism also from lay people, witnesses the fact, that, in the face of increasing persecution of the Church in France, she presented to the aforementioned Margaret Gollot the perspective of joint martyrdom ${ }^{17}$.

For the French Carmelite the measure of the union with God is love awakened through the Holy Spirit, who from the very moment of baptism with the other Persons of the Holy Trinity, dwells in the soul of Christians. In modern lay people's spirituality the common call to holiness - consisting of the perfect realization of total love through the obedience to the will of God - is emphasized ${ }^{18}$. The Carmelite theologian Marie-Jean de la Rédemption even writes about the common call to the mystic life, based on the fact, that the principle of mystic life is the development of the theological life - especially of love. He even states, that the holiness of the members of the Church is of a mystical order ${ }^{19}$.

In the similar way E. Ancilli shows this question, saying that many authors consider the mystical life, as a spiritual life, in which the influence of the Holy Spirit dominates. This influence is so elevated, that in order to explain it, the virtues are not enough. One has to refer to the gifts of God bestowed to the soul as a help to the virtues. Here the author differentiates contemplation from holiness as heroic virtue, where the soul is moved by the Holy Spirit. That is why the soul can be mystical without experiencing contemplative states. The gifts of the Holy Spirit can act - in a broad sense - in the life of the soul, without causing the state of infused prayer, in which the soul itself feels 'captured' by God. The hidden

\footnotetext{
${ }^{13}$ See ibid, p. 307, 330.

${ }^{14}$ See Élisabeth de la Trinité, Śuvres Complètes, p. 101, 114, 181.

${ }^{15}$ See ibid, p. 125-127.

${ }^{16}$ See ibid, p. 498.

${ }^{17}$ See ibid, p. 306.

${ }^{18}$ See P. Brugnoli, La spiritualità dei laici, Brescia 1965, p. 13-17; C. García, Espiritualidad de los laicos, Burgos 2004, p. 125.

${ }^{19}$ See Marie-Jean de la Rédemption, L'appel universel à la mystique, "Carmel" (1999) 3/93, p. 87-92.
} 


\section{The Person and the Challenges \\ 142 Volume 1 (2011) Number 2}

action of the gifts can be imperceived by the soul, which is not very conscious of its passivity, although with time, it should somehow gain awareness of this action. A good example of such an experience is Saint Theresa of the Infant Jesus. In spite of the lack of mystical contemplation, she was habitually influenced by the Holy Spirit. She was consumed by the desire of love and it meant that she was drawn to God. Although God enlightened her internally about what she should do, it did not however introduce a contemplative state in her. According to Saint Thomas Aquinas, the gifts of the Holy Spirit help the virtues, which need the gifts to reach heroic perfection. Therefore the mystical life is a life in which the influence of the Holy Spirit dominates more and more, together with certain contemplative knowledge, but not necessarily a contemplative state. In this way Ancilli differentiates the contemplative and the usual, but mystical way. That is why according to him, all Christians are called to holiness, but not all to the contemplative experiences par excellence. Consequently, all Christians are called to mystical life, that is to the fullness of the Christian life in which the acting of the Holy Spirit dominates, causing Christ to live in a Christian. Here holiness and the mystical life join together and even identify with one another ${ }^{20}$.

\section{The complementarity of action and contemplation}

In the modern spirituality according to Ignatius of Loyola, Francis de Sales, Teresa of Avila and John of the Cross, the essential elements of Christian spirituality, like action and contemplation, ascetism and mysticism, Christian perfection and holiness, join harmoniously together as a whole. The different dosages of these elements let different schools of modern spirituality develop, which are the sources of inspiration of the lay people's spirituality. The aforementioned authors confirm, that contemplation and apostolate help each other. The time dedicated to contemplation is regained a hundred times in the apostolate because the soul united with Christ participates in his omnipotence ${ }^{21}$.

In this field the real mistress was St. Teresa of Avila. She used to say that the Lord wanted works. One can understand it as a necessity to more active engagement in the building up of the Kingdom, or more mystically, that the apostolate should be first received from the Holy Spirit as the answer to the love of God. The perfect example of the second way was the saint herself who delivered

${ }^{20}$ See E. Ancilli, Santità, in: Dizionario di spiritualità dei laici, vol. 2, Milano 1981, p. 265.

${ }^{21}$ See F.X. von Hornstein, Apostolat und inneres Leben, "Anima. Vierteljahrschrift für praktische Seelsorge" (1959), p. 125. 
an authentic mystical doctrine, concerning apostolic activity. In her opinion the apostolic effectiveness depends closely on striving towards holiness, especially by inner prayer. To see clearly the power and mercy of God and the weakness of man is constitutive for the spiritual life - particularly for the apostolic one - which is the answer to the gift of loving God, the main source of apostolate. In order to be deeply involved in the activity, the apostle should work out within himself the habit of looking for God. For Teresa there was no competition between looking for a union with God and apostolate, which however should draw strength from the divine source. It was essential for her that the fulfilled works would be more and more inspired by the Holy Spirit and not by other motivations. It is exactly the contemplative prayer which causes such a 'broadening of the soul' that it discovers in the faith wider and wider apostolic horizons, exceeding purely human projects, until mystical marriage, in which contemplation and action, symbolically represented by Mary and Martha, are experienced in an extraordinary intensive and harmonized way. Here, the Lord himself fulfills his apostolic works through man. The result of this is, that the imitation of Christ, whose 'food' was to do the will of the Father, is the driving force of the apostolic life. The apostolate of love is in the very heart of Teresian apostolic mysticism. The works to which she incessantly exhorted, have their only source in love. The Christian apostolate consists of living and emitting love, because the soul which loves, is necessarily apostolic. Growth in love and apostolic zeal are interdependent. The apostolate also contributes to the development of the mystical life. Especially interesting is the fact, that for Teresa apostolate feeds contemplation. For her apostolate was a means of sanctification, but was also the stage of the struggle between light and darkness. Particularly on the upper levels of the spiritual life - in the sixth and seventh mansion - the activity gains all its sanctifying effectiveness, as everything becomes an occasion for spiritual progress. Here the action and the contemplation are equally uniting, for in both pours forth the fullness of love. According to Teresa, an apostle is called to experience 'Passover of activity', so that he, as a result of long and painful purifications, comes to such a detachment and receptivity, which enable him to become obedient to the inspirations of the Holy Spirit. Experiencing his spiritual poverty, the apostle discovers the absolute priority of God, and necessity of total abandonment to His mercy. That's why he gives in the hand of God the fruits of the apostolic pains, which he received from $\mathrm{Him}^{22}$. It is by no means possible to separate the teaching of apostolate from the doctrine of contemplation in the Teresian system. In this spirituality the

${ }^{22}$ See F.-R. Wilhélem, Dieu dans l'action. La mystique apostolique selon Thérèse d'Avila, Venasque 1992, p. 307-340. 


\section{The Person and the Challenges \\ 144 Volume 1 (2011) Number 2}

contemplation and apostolate join together and complement one another. They are two aspects of the same life.

This issue is closely connected to the desire of achieving the ideal in the form of constant prayer. The Christian existence is the realization of two dimensions - vertical and horizontal - i.e. transcendental and incarnational. All groups in the Church, but especially lay people, should - in the process of discernment of spirits - discover their own place on the axis 'prayer' or 'engagement in the temporal order'. According to Thils, the secret of the constant prayer doesn't consist of mixing more and more prayer in the work, but of converting that whole work into prayer. In this case it is possible to reconcile the requirements of Saint Paul to pray 'constantly' ( 1 Tess 5,17$)$ and work 'night and day' $(2 \text { Tess } 3,8)^{23}$. So work may also become prayer thanks to the constant increase of the theological love, however without neglecting the formal prayer. If a man of action contemplates, God sends him tasks. Such was the attitude of - for instance - Teresa of the Infant Jesus $^{24}$. Constant prayer means the life is totally dedicated to God's service according to His recognized, wanted, loved and blessed will. Such a prayer is an encounter, a communion, moving in the 'space' of God, and a cooperation with His will. For a person focused on the presence of God, the constant prayer is possible in the very heart of the most engaging action, for it is an expression of the constant love. In the case of a lay person it will often be a sober mystic, as patient and meditative dealing with the daily things, and a pious lasting in the face of their materiality till they 'open' and liberate a way to this, which is reflected in them ${ }^{25}$.

\section{Incarnational spirituality in the light of the conditions of the mystical life}

The first move of faith is to give everything to God. From the beginning of Christianity the eschatological, ascetical and monastic ideas show, how interest in the absolute aim turns the attention from earthly matters, although the Church has never seen that the desert is the only adequate place for its existence ${ }^{26}$. Because

${ }^{23}$ See G. Thils, Les laïcs et l'enjeu des temps "post-modernes", Cahiers de la revue théologique de Louvain 20, Louvain-la-Neuve 1988, p. 105-109.

${ }^{24}$ See Y. Congar, Laïc et Laïcat, in: Dictionnaire de spiritualité, vol. 9, Paris 1976, p. 106.

${ }^{25}$ See A. Auer, Weltoffener Christ. Grundsätzliches und Geschichtliches zur Laienfrömmigkeit, Düsseldorf 1966, p. 206-210.

${ }^{26}$ See F. J. Schierse, Eschatologische Existenz und christliche Bürgerlichkeit, "Geist und Leben” 32 (1959), p. 280. 
the lay Christian by God's will should be the 'Church' there, where the world is, his spirituality cannot be a resignation from the world in the meaning of the three religious vows, but rather a striving for perfection through an engagement in the world. In this way, the theology of earthly realities came into existence, and its central problem was to reconcile the love to God with the love to the world, which resulted in a new type of spirituality of the incarnation, emphasizing especially the truth of God's becoming man ${ }^{27}$. One began to talk more and more about the consecration of the world - saturating it with the spirit of the Gospel - which seems to be a special vocation of the lay people.

It begs the question about the relation to the world in the context of mystical life. Sometimes the gnostic understanding of 'spiritual man', as one who distances himself from the body and matter and not as one who lets himself be led by the Holy Spirit, caused the escape from the world (fuga mundi) and even the heresies, like encratism, montanism or messalianism, although the orthodox teaching of the Church repeatedly emphasized that creatures are not bad and life in the world is not a sin. Although it was never about undermining the value of God's creatures, J. Daniélou regarded the pedagogical depreciation of creatures in spirituality as justified, because, according to him, dedicating them too much attention, makes them dangerous. However this is not an ontological depreciation. In this sense in his opinion - it's necessary to distinguish 'the dark night' of Saint John of the Cross, from the statement by Saint Thomas Aquinas, that 'omne ens est bonum'. That is why, it is a misunderstanding to make from the 'dark night' an ontological rule, and from the ontological, positive evaluation of the creatures, a rule of spirituality. A. Auer does not agree with him, underlining that the statement 'omne ens est bonum' can be a rule of spirituality, without forgetting the sin-related corruption of creatures, which makes the depreciation in this sense, obvious ${ }^{28}$.

Also for Saint John of the Cross, creatures stimulate man to love their Creator and each of them has in itself some aspect of God's perfection. But the Creator is infinitely more worthy to be loved, than all of them together, therefore while developing theological virtues, man should direct himself above all to God. In this sense, the Carmelite saint Teresa Benedicta of the Cross (E. Stein) wrote that she would enter the order leaving behind the world not considering it worthless, but so as to be totally free for God ${ }^{29}$. It should not be forgotten that

${ }^{27}$ See R. Bultot, Teologie des réalités terrestres et spiritualité du lä̈cat, "Revue internationale de théologie Concilium" 19 (1966), p. 45.

${ }^{28}$ See J. Daniélou, Les conseils évangeliques, "La Vie Spirituelle" 30 (1948), p. 665.

${ }^{29}$ See E. Stein, Selbstbildnis in Briefen. Briefe an Roman Ingarden, Freiburg-Basel-Wien 2001, p. 237 . 


\section{The Person and the Challenges \\ 146 Volume 1 (2011) Number 2}

because of original sin, all creatures, to some extent, became spoilt. According to E. Stein they are still a mirror of God's perfection, but a broken one. Their relation to the Creator shows some 'similitudo', but also 'maior dissimilitudo'. In her interpretation of Saint John of the Cross' doctrine, only when the soul receives infused knowledge of God and He becomes everything for it, then it finds a picture of His perfection in creatures. Thus the knowledge of God reveals before the soul a new, wonderful world ${ }^{30}$. At this point the difference in accent between the spiritualities of transcendence and of incarnation seems to be the most visible. In the latter, also for a lay person, the first and most important value is love of God above all. However the style of this love does not consist of throwing oneself at Him over and beyond everything, to find later in Him oneself and creatures, but of seeking Him out inside the life of the world as a basis, strength, life, love and certainty of everything that exists. The lay person in the world should be able to experience possibilities of finding God in everything. In order to fulfill the Christian life, God attracts the person who believes, loves and hopes in Him. This attraction causing love and openness to God lets the person also psychologically perceive Him as present in every act animated by faith and love. This according to Brugnoli constitutes the great mystical experience of the lay people ${ }^{31}$. Such a mystic of 'everyday life', that is finding God's presence in the world, which abolishes the contrariness of simultaneous love of both, was developed by K. Rahner, F. von Hügel and Teilhard de Chardin ${ }^{32}$.

The character of the attitude to the world is shown by the accepted conception of ascetics. Traditional ascetics of the monastic type is often criticized for the lack of 'incarnational power', extreme individualism, a lack of responsibility for the world and destructive practices, suppressing spiritual energies. All the more, sometimes the sacrifice of the lay people seems to be more concrete, in comparison with the full security of the life of religious ${ }^{33}$. Edith Stein was ashamed when her life in the Carmel was spoken about as a sacrifice. In her opinion she led a life of sacrifice in the world, and in Carmel almost all her burdens were taken from her $^{34}$. Without questioning the value of the traditional form of monastic ascetics, it should be asked, whether a holy lay person must live in inner detatchment

\footnotetext{
${ }^{30}$ See E. Stein, Kreuzeswissenschaft, p. 204.

${ }^{31}$ See P. Brugnoli, La spiritualità, p. 139-149.

${ }^{32}$ See H. Egan, I mistici e la mistica. Antologia della mistica cristiana, Città del Vaticano 1995, p. 667,669 .

${ }^{33}$ See P. Brugnoli, La spiritualità, p. 18-26.

${ }^{34}$ See E. Stein, Selbstbildnis in Briefen. Zweiter Teil (1933-1942), Freiburg-Basel-Wien 2000, p. 103.
} 
from the world like, for instance, Saint John of the Cross. According to Brugnoli a person seized by God's love is able to love and use the world 'in a pure manner'. He can effectively and affectively engage himself, remaining 'detached' due to the highest love of Christ. It's not about escaping the world (fuga mundi), but about going beyond it in the love of Christ. It is about balance, which does not make of ascetics the absolute value, as if God did not order people to accept the world and bring it under control, but also does not make absolute the world, as if the first value was not the love of $\operatorname{God}^{35}$.

The new ascetics emphasizes the indirect overcoming of evil by being good Christians, who fulfill duties, accept defeat and totally give themselves to the guidance of the Holy Spirit. There is no reason that new ascetics couldn't lead to holiness, because the total renouncement of oneself, being the condition of total love, does not always need to take on the form described by Saint John of the Cross. The holy Christian can reach these heights in the world and through it, making his life more and more full of service and love, to finally abandon his own 'self' and live entirely for God and his neighbour. In this sense the lay person 'exercises' mortification directly in marriage and work, i.e. in the context of the world ${ }^{36}$. The requirement of the total renunciation in the Gospel $(\mathrm{Lk} \mathrm{14,26)}$ is a correlative of the law of total love (Mt 22,37). Self-abnegation and neighbourly love, as well as spiritual poverty and contemplation in the system of Saint John of the Cross, are directly related to each other. Entrusting oneself entirely to Christ means renouncing egoism. The full life in the Spirit is reached through ascetics, complemented by the grace of passive purgation and mystical graces. In the past the ascetics-emphasized the negative pole, aiming at mastering nature, according to the rule, that the purification of the soul from all creatures lets God fill it with Himself. In the foreground were renunciation, penance and sacrifice in the life dominated by the cross. Nowadays one considers this kind of ascetics to be a little bit artificial and thus aims at spirituality focused on the resurrection. People do not accept the cross without the resurrection and do not understand a system, which would separate them from the life closely connected with their neighbours. However they are ready for self-abnegation, which means love for God, the neighbour and the world ${ }^{37}$.

\footnotetext{
${ }^{35}$ See P. Brugnoli, La spiritualità, p. 179-191.

${ }^{36}$ See E. Larkin, Die Askese im modernen Leben, "Internationale Zeitschrift für Theologie Concilium" (1966), p. 706.

${ }^{37}$ See ibid, p. 703.
} 


\section{Conclusion}

Nowadays, in many societies, one can perceive a renewed interest in religion in the aspect of concentration, contemplation and encounter with the sacrum. In order that these strivings would not end as esoteric attitudes, or a mere romanticism, the constant inner work based on the effort of mind and will is needed. The ability to connect the desire for religious experience with the institution of faith is also needed ${ }^{38}$. After the Second Vatican Council the incarnational spirituality of the lay people is no more an escape from the world, but 'immersion' in it, with the desire to change it according to God's plan. It does not mean that a lay person has to forget about the transcendence and the distance to the world. However such a distance is not a lack of interest, but an approach to the world with the perspective of redemption. It is about everyday mysticism, in other words about a contemplative outlook on life's daily realities, placing special care on the theological life, whose master is Saint John of the Cross. From our considerations it occurs however, that every Christian, together with God's life of grace bestowed in baptism, receives the basis for the mystical life. Neither an active life in the world, nor work or marriage, hinders the development of this gift.

\section{Bibliography}

Auer A., Weltoffener Christ. Grundsätzliches und Geschichtliches zur Laienfrömmigkeit, Düsseldorf 1966.

Brugnoli P., La spiritualità dei laici, Brescia 1965.

Élisabeth de la Trinité, Śuvres Complètes, Paris 2002.

García C., Espiritualidad de los laicos, Burgos 2004.

Juan de la Cruz, Obras Completas, Salamanca 2002.

Stein E., Kreuzeswissenschaft. Studie über Johannes vom Kreuz, Freiburg im Breisgau 2003.

Thils G., Les laïcs et l'enjeu des temps "post-modernes", Cahiers de la revue théologique de Louvain 20, Louvain-la-Neuve 1988.

${ }^{38}$ See J. Ratzinger, Abbruch und Aufbruch. Die Antwort des Glaubens auf die Krise der Werte, Eichstätter Hochschulreden 61, München 1988, p. 10-12. 